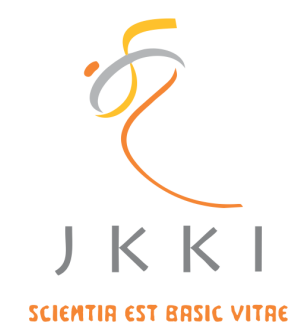

Jurnal Kedokteran dan Kesehatan Indonesia

Indonesian Journal of Medicine and Health

Journal homepage: https://journal.uii.ac.id/JKKI

\title{
Prevalence of constipation and lifestyle risk factors related to constipation in an adult population of South Tangerang
}

Hoirun Nisa*1

${ }^{1}$ Department of Public Health, Faculty of Health Sciences, Universitas Islam Negeri Syarif Hidayatullah, Jakarta, Indonesia

Original Article

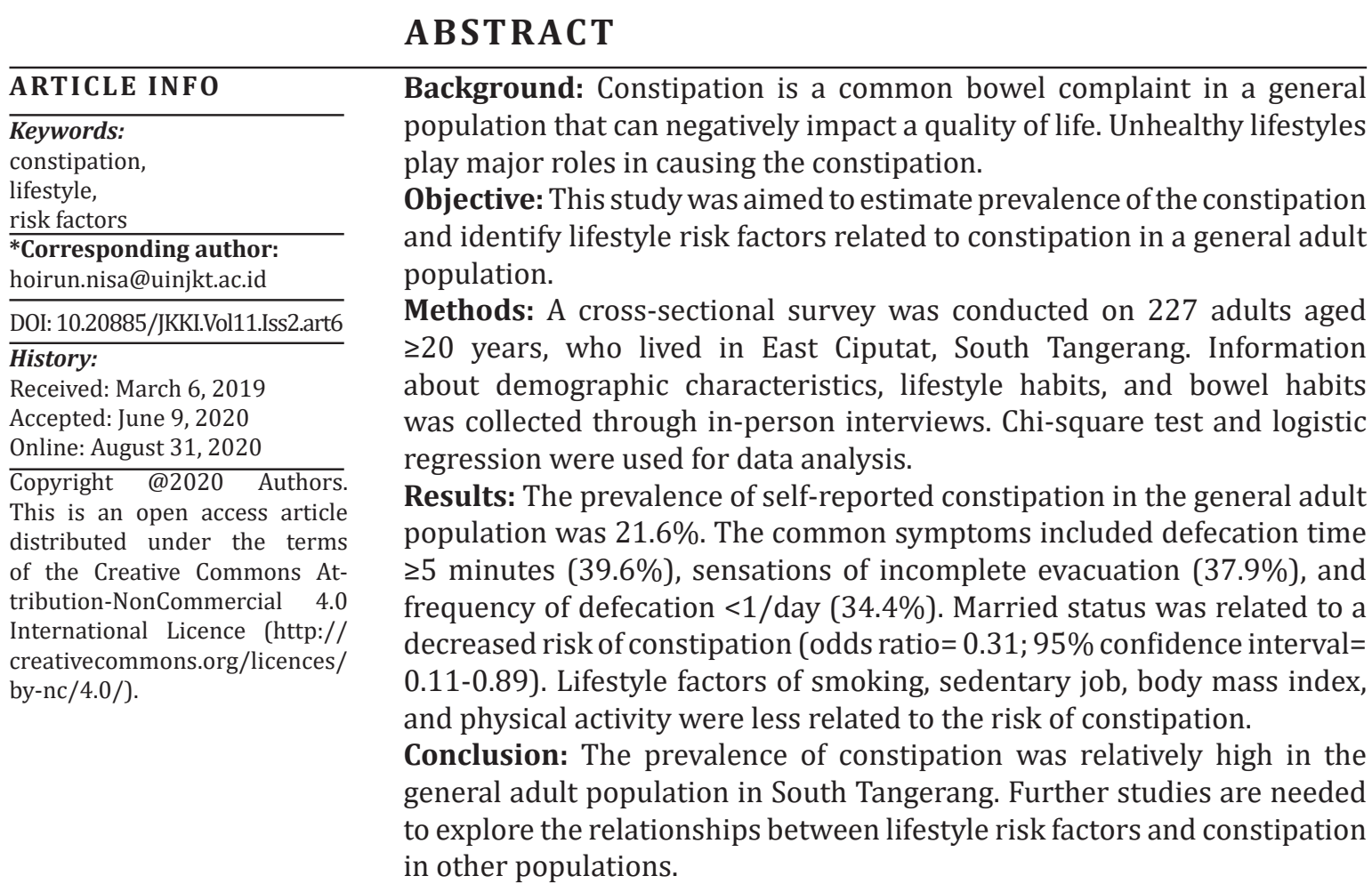

Latar Belakang: Konstipasi/sembelit adalah keluhan yang umum di populasi dan dapat berdampak negatif terhadap kualitas hidup. Gaya hidup yang tidak sehat mempunyai peran penting dalam menyebabkan konstipasi.

Tujuan: Penelitian ini bertujuan untuk memperkirakan prevalensi konstipasi dan mengidentifikasi faktor risiko gaya hidup yang berhubungan dengan konstipasi pada orang dewasa.

Metode: Desain penelitian kros-seksional digunakan dengan melibatkan 227 orang dewasa berumur $\geq 20$ tahun, yang tinggal di Ciputat Timur, Tangerang Selatan. Informasi mengenai karakteristik demografi, gaya hidup, dan kebiasaan buang air besar dikumpulkan dengan wawancara langsung. Data dianalisis menggunakan uji chi-square dan analisis regresi logistik.

Hasil: Prevalensi konstipasi pada orang dewasa ditemukan sebanyak 21.6\%. Gejala umum konstipasi antara lain waktu buang air besar $\geq 5$ menit (39.6\%), sensasi tidak lengkap (37.9\%), dan frekuensi buang air besar $<1$ / hari (34.4\%). Status menikah berhubungan dengan penurunan risiko konstipasi (odds rasio $=0.31 ; 95 \%$ interval kepercayaan $=0.11-0.89)$. Faktor risiko gaya hidup merokok, pekerjaan sedentary, indeks massa tubuh, dan aktifitas fisik tidak berhubungan dengan risiko konstipasi.

Kesimpulan: Prevalensi konstipasi cukup tinggi pada orang dewasa di Tangerang Selatan. Penelitian lebih 
lanjut diperlukan untuk mengeksplorasi hubungan antara faktor risiko gaya hidup dengan konstipasi pada populasi lainnya.

\section{INTRODUCTION}

Constipation is a common symptom characterized by unsatisfactory defecation that results from infrequent stools, difficult stool passage, or feeling of incomplete defecation. ${ }^{1}$ Many studies have assessed prevalence of constipation in general adult populations, and their findings are highly heterogeneous with prevalence rates ranging from $2.6 \%$ to $30 \%$. $^{2-}$ ${ }^{4}$ However, there are very limited studies on constipation in Indonesian adults, and one of them can be seen in a cross-sectional study in Banda Aceh reporting that prevalence of constipation among adult participants was $66.7 \% .{ }^{5}$ Even though constipation is largely unreported and its complaint is when only in a chronic condition, mounting evidence have indicated that chronic constipation affects a person's health-related quality of life, resulting from economic burden for both its patients and healthcare systems. ${ }^{6-10}$

Previous studies have found that constipation is related to many factors such as age, gender, socioeconomic status, dietary habit, education level, anxiety, depression and psychological factor. ${ }^{1,11}$ In addition, chronic constipation is more common in women with rates of 2 to 3 times higher than in men., ${ }^{3,12}$ Although many studies have assessed magnitude of functional constipation and its factors in other countries, evidence from Indonesia is limited. Furthermore, better understanding of the constipation prevalence in adult population and its related lifestyle characteristics can benefit for its management. The aims of this study were to measure the prevalence of constipation and identify lifestyle factors with occurrence of constipation in adults from the general population.

\section{METHODS}

\section{Study design and participants}

Data of this study were derived from a cross- sectional study conducted from June to November 2015 in East Ciputat, South Tangerang. The participants were adults defined by the World Health Organization (WHO), and they were living in the East Ciputat of South Tangerang District. ${ }^{13}$ A purposive sampling technique was used to select participants. Eligible participants were adults whose age were at least 20 years old living in the study area, had never been diagnosed to have fecal incontinence, and were mentally competent to give informed consent and to complete theinterview. Sample size of this study was calculated by using adults' constipation prevalence of $30 \%$, power level of $80 \%$, confidence level of $95 \%$, and odds ratio of 2.2. ${ }^{4}$ It was required at least 238 participants in data analysis. A total of 250 eligible participants were then contacted to participate in this survey, but 23 individuals were not able to participate during the study so that a total of 227 participants was in the final analysis (response rate $=90.8 \%$ ). Written consent was obtained from all the participants, and the study protocol was approved by the Research Ethics Committee of the Faculty of Medicine and Health Sciences, Universitas Islam Negeri Syarif Hidayatullah (UIN) Jakarta Indonesia.

\section{Data collection}

In-person interview was conducted at participations' houses by well-trained interviewers by using a structured questionnaire, which included demographic characteristics (gender, age, education, and marital status), lifestyle habits (smoking habit, types of job, and physical activity), and bowel habits. Bowel habits in at least three months before the study were ascertained by closed-ended questions regarding constipation, frequency of bowel movements, consistency of stool, abdominal distention, feeling of incomplete evacuation, time required for defecation, regularity of bowel movements, and use of laxatives. Eight answers were prepared for the question on the frequency of bowel movements, and 5 answers were given to the question on the time for defecation. In 
the analysis, frequency of bowel movements and consistency of stool were divided into 3 categories. Regularity of the bowel habit and feeling of incomplete evacuation were answered dichotomously. Three to four answers were prepared for the remaining questions, and they were further divided into 2 categories in the analysis. Referring to Rome III criteria, functional constipation was defined if two or more of the following five symptoms during the last 3 months (minimum) before this study were reported.The symptoms were less than one bowel movement per 3 days, having hard stools, feeling of incomplete evacuation, taking more than 5 minutes to have a bowel movement, and laxative use more than once per week. ${ }^{14}$

Body mass index (BMI, $\mathrm{kg} / \mathrm{m}^{2}$ ) was estimated by reporting height $(\mathrm{cm})$ and body weight $(\mathrm{kg})$. Smoking habit was categorized into non-smoking and ever smoking. Information of types of job and physical activities was ascertained. Types of job were categorized into sedentary (clerical work, taxi driving, housework), work with walking (delivery by walking, patrolling on foot), labor work (construction work, agricultural work, load transport), hard labor work (digging or chopping with heavy tools, carrying heavy loads), and no job (including students). ${ }^{15,16}$ Physical activities were expressed as a sum of metabolic equivalents (MET) multiplied by hours of weekly participation in each activity. In the analysis, the types of job and physical activities were divided into 2 categories.

\section{Statistical analysis}

Descriptive data were presented by using means, standard deviations, or frequency as indicated. Comparisons between constipation groups (yes/no) were conducted by the $\chi^{2}$ test for categorical data and by $t$ test for continuous data (age, height, and BMI). Variables with $p$-value $<0.250$ on the bivariate analysis were entered to multivariate logistic regression model to identify their independent effects. $p$-value and $95 \%$ confidence interval (CI) for odds ratio (OR) were used to determine significances of relationships of the obtained data. A two-sided p-value $<0.05$ was considered as statistically significant. Statistical analyses were calculated by using SPSS software (SPSS, Inc., version 17.0).

\section{RESULTS}

More than half of participants (61\%) were female and their mean age was 48.9 years. Majority of them were married ( $80 \%$ ), and more than half of them had high school degree (57\%). Mean height and BMI were $158.4 \mathrm{~cm}$ and 23.7 $\mathrm{kg} / \mathrm{m} 2$, respectively, while $39 \%$ of them had BMI $\geq 25 \mathrm{~kg} / \mathrm{m} 2$ and were classified as overweight. A $26 \%$ of them were ever smokers, $16 \%$ of them had sedentary job, and $26 \%$ were physically active (Table 1).

Table 1. Characteristics of participants

\begin{tabular}{lc}
\hline Characteristics & $\mathbf{n}$ (\%) \\
\hline Gender & \\
Female & $139(61.2)$ \\
Male & $88(38.8)$ \\
Age, year** & $48.9 \pm 11.9$ \\
Education & \\
Elementary school & $50(22.2)$ \\
High school & $128(56.4)$ \\
University & $49(21.6)$ \\
Marital status & \\
Single & $22(9.7)$ \\
Married & $181(79.7)$ \\
Widowed/divorced & $24(10.6)$ \\
Height, cm** & $158.4 \pm 5.8$ \\
BMI, kg/m ${ }^{2 * *}$ & $23.7 \pm 4.5$ \\
Ever smoking & $59(26.0)$ \\
Sedentary job & $37(16.3)$ \\
Physically active & $59(26.0)$ \\
*Number & \\
$* *$ Data are presented as mean \pm standard \\
deviation
\end{tabular}

Table 2 shows prevalence of constipation and bowel habit characteristics of the participants. The prevalence of self-reported constipation was $21.6 \%$, and functional constipation was 
defined for $29.1 \%$ based on Rome III criteria. The frequency of bowel movement of $<1$ per day was $34.4 \%$, while stool consistency reported as hard was $10.1 \%$. A $55.1 \%$ of participants had abdominal distention , 37.9\% were in incomplete evacuation, $39.6 \%$ had defecation time of $\geq 5$ minutes, $13.7 \%$ experienced irregular bowel movement, and $10.1 \%$ used laxatives (Table 2 ).

Table 2. Prevalence of constipation and bowel habit characteristics

\begin{tabular}{lc}
\hline Bowel habit characteristics & $\mathbf{n}$ (\%) \\
\hline Self-reported constipation & $49(21.6)$ \\
Functional constipation & $66(29.1)$ \\
Stool frequency & \\
$>1 /$ day & $24(10.6)$ \\
$1 /$ day & $125(55.1)$ \\
$<1 /$ day & $78(34.4)$ \\
Stool consistency & \\
Hard & $23(10.1)$ \\
$\quad$ Normal & $177(78.0)$ \\
Loose & $27(11.9)$ \\
Abdominal distention & \\
No & $102(44.9)$ \\
Yes & $125(55.1)$ \\
Incomplete evacuation & \\
No & $141(62.1)$ \\
Yes & $86(37.9)$ \\
Defecation time, minutes & \\
$<5$ & $137(60.4)$ \\
$\geq 5$ & $90(39.6)$ \\
Regularity & \\
Regular & $196(86.3)$ \\
Irregular & $31(13.7)$ \\
Laxative use & \\
No & $204(89.9)$ \\
Yes & $23(10.1)$ \\
\hline Number & \\
\hline
\end{tabular}

Self-reported constipation according to demographic and lifestyle factors are presented in Table 3. The constipation was higher in female than in male, while mean $( \pm S D)$ age of participants reporting constipation and without constipation were $49.4( \pm 0.8)$ years and $47.1( \pm 1.7)$ years, respectively. Participants with constipation were more likely to have high school degree, less likely to be married, taller, and lower in their BMI, 
and more physically active than those without constipation. Ever smoking and sedentary job were more frequent in participants with constipation than those without constipation. In addition, married status was significantly related to self-reported constipation (Table 3).

Table 3. Self-reported constipation according to demographic and lifestyle variables

\begin{tabular}{|c|c|c|c|}
\hline \multirow{2}{*}{ Characteristics } & Constipation & Without constipation & \multirow{2}{*}{ p-value } \\
\hline & $n^{*}(\%)$ & $n^{*}(\%)$ & \\
\hline \multicolumn{4}{|l|}{ Gender } \\
\hline Female & $29(59.2)$ & $110(61.8)$ & - \\
\hline Male & $20(40.8)$ & $68(38.2)$ & 0.74 \\
\hline Age, year** & $47.1 \pm 1.7$ & $49.4 \pm 0.8$ & 0.20 \\
\hline \multicolumn{4}{|l|}{ Education } \\
\hline Elementary school & $12(25.5)$ & $38(21.5)$ & - \\
\hline High school & $28(59.6)$ & $100(56.5)$ & 0.76 \\
\hline University & $9(18.4)$ & $40(22.5)$ & 0.49 \\
\hline \multicolumn{4}{|l|}{ Marital status } \\
\hline Single & $10(20.4)$ & $12(6.7)$ & - \\
\hline Married & $34(69.4)$ & $147(82.6)$ & 0.01 \\
\hline Widowed/Divorced & $5(10.2)$ & $19(10.7)$ & 0.08 \\
\hline Height, $\mathrm{cm}^{* *}$ & $160.4 \pm 1.3$ & $157.9 \pm 0.6$ & 0.08 \\
\hline BMI, $\mathrm{kg} / \mathrm{m}^{2 * *}$ & $23.3 \pm 0.7$ & $23.9 \pm 0.3$ & 0.37 \\
\hline \multicolumn{4}{|l|}{ Smoking } \\
\hline Non-smoking & $36(73.5)$ & $131(73.6)$ & - \\
\hline Ever smoking & $13(26.5)$ & $47(26.4)$ & 0.79 \\
\hline \multicolumn{4}{|l|}{ Type of job } \\
\hline Non-sedentary & $38(77.6)$ & $152(85.4)$ & - \\
\hline Sedentary & $11(22.4)$ & $26(14.6)$ & 0.19 \\
\hline \multicolumn{4}{|l|}{ Physical activity } \\
\hline No & $33(67.4)$ & $135(75.8)$ & - \\
\hline Yes & $16(32.6)$ & $43(24.2)$ & 0.23 \\
\hline
\end{tabular}

${ }^{*}$ Number; ${ }^{* *}$ Data are presented as mean \pm standard deviation

Table 4 presents crude and adjusted ORs for self-reported constipation of the adults. The ORs for body height and sedentary job were greater than unity. Participants who were married and physically active showed a moderate decrease in ORs of constipation, and the decrease in the
ORs in married participants was statistically significant in multivariate analysis. Repeated analysis for functional constipation showed similar results with those of self-reported constipation. 
Table 4. Crude and Adjusted ORs for self-reported constipation among adults

\begin{tabular}{|c|c|c|c|c|}
\hline Characteristics & $\mathbf{n}^{*}$ & Crude OR (95\% CI) & Adjusted OR (95\% CI) & P value \\
\hline Age, year & $49 / 178$ & $0.98(0.96-1.01)$ & $1.00(0.96-1.03)$ & 0.93 \\
\hline \multicolumn{5}{|l|}{ Marital status } \\
\hline Single & $10 / 12$ & 1.00 & 1.00 & \\
\hline Married & $34 / 147$ & $0.28(0.11-0.69)$ & $0.31(0.11-0.89)$ & 0.02 \\
\hline Widowed/Divorced & $5 / 19$ & $0.32(0.09-1.15)$ & $0.42(0.09-1.89)$ & 0.26 \\
\hline Height, $\mathrm{cm}$ & $49 / 178$ & $1.03(1.00-1.07)$ & $1.02(0.98-1.06)$ & 0.25 \\
\hline \multicolumn{5}{|l|}{ Type of job } \\
\hline Non-sedentary & $38 / 152$ & 1.00 & 1.00 & \\
\hline Sedentary & $11 / 26$ & $1.69(0.77-3.72)$ & $1.56(0.67-3.62)$ & 0.30 \\
\hline \multicolumn{5}{|l|}{ Physical activity } \\
\hline No & $33 / 135$ & 1.00 & 1.00 & \\
\hline Yes & $16 / 43$ & $0.66(0.32-1.31)$ & $0.84(0.40-1.78)$ & 0.65 \\
\hline
\end{tabular}

*Number of self-reported constipation/without constipation

\section{DISCUSSION}

In this study, the prevalence of constipation was relatively high. Marital status was significantly related to a decreased risk of constipation. However, this study indicated that lifestyle factors of smoking, sedentary job, BMI, and physical activity were less related to risks of constipation.

Constipation can be caused by various factors, including primary and secondary causes. Primary causes are intrinsic problems of colonic or anorectal function, whereas secondary causes are related to diseases or medications. ${ }^{17}$ In addition, the constipation is variously defined according to self-reported constipation and formal criteria. ${ }^{18}$ The findings in this study showed that the prevalence of constipation was $21.6 \%$ for self-reported constipation and $29.1 \%$ for functional constipation based on Rome III criteria. These findings were similar to prevalence of $26.9 \%$ by the Rome III criteria and $25.6 \%$ of prevalence by self-reporting in general Brazilian adult population. ${ }^{19}$ Increased rates were also reported in South Korea (25.8\%), France (22.4\%), and Iran (22.9\%) ${ }^{20-22}$ However, lower prevalence rates (14.6\% and $2.1 \%$ ) were found in Brazil and Spain. ${ }^{23-24}$ Constipation was defined by the Rome III criteria in the earlier study and on self-reports in the latter study. The -various results may be partially due to different variability in methods used to measure the prevalence, including differences in criteria to define constipation and the age distributions of population study. ${ }^{3,4}$

In this study, the most frequent symptom of constipation was abdominal distention (55.1\%), followed by defecation time $\geq 5$ minutes (39.6\%), sensations of incomplete evacuation (37.9\%), and frequency of defecation $<1 /$ day (34.4\%). Similarly, findings from a systematic review showed that Asians perceived a range of symptoms at varying frequency from $10 \%$ to $98.4 \%$, whereas straining, incomplete evacuation, and hard and lumpy stool were symptoms reported more frequently among adult Asians. ${ }^{25}$ In the West countries, hard and lumpy stool was more frequent than the sensation of incomplete evacuation. ${ }^{25}$ These findings suggest that adult participants perceived constipation somewhat differently as any form of difficult defecation, while health care professionals typically define constipation by the frequency of bowel movements. ${ }^{20,26}$

Potential lifestyle risk factors for constipation were also evaluated in this study. Previous studies reported that constipation was more 
perceived by females than by males. $2,6,11,20,27$ Some studies also observed that the prevalence rates increased with age. ${ }^{1,4,23}$ In this study, selfreported constipation was not significantly different in relation to participants' gender, age, and level of education. Interestingly, this study found that constipation was significantly lower in married individuals. Marital status affected the level of constipation misperception although development of chronic constipation was not influenced by marital status. ${ }^{28,29}$ It is likely that married individuals may have better recognition of constipation symptoms because their potentially constipated spouses inform these individuals about the symptoms. Poor lifestyle habits have also been suggested as important risk factors for constipation; however, this study did not observe the relationships of smoking, sedentary job, BMI, physical activity with the constipation. ${ }^{30}$

Advantages of this study included that bowel habits were evaluated among adults in the community, and that multi-facets of bowel habits were evaluated in relation to self-reported constipation. However, several limitations of this study should be acknowledged. For example, other factors potentially related to constipation such as dietary habits, medications, and multiple comorbid conditions were not examined in this study. In addition, a causal relationship between constipation and risk factors could not be determined due to cross-sectional design.

\section{CONCLUSION}

The prevalence of self-reported constipation in this general adult population was moderately high (21.6\%). Marital status was related to a a decreased risk of constipation. Lifestyle factors of smoking, sedentary job, BMI and physical activity were unrelated to the risks of constipation. Further studies with larger sample and long-term follow-up are required to explore the relationships between these factors and the risk of constipation in other populations.

\section{CONFLICT OF INTEREST}

None

\section{ACKNOWLEDGEMENT}

The author thanks to students Epidemiology Program, Public Health Faculty of Health Sciences UIN Syarif Hidayatullah Jakarta for assisting in collecting data. The author also thanks to participants for their participation in this survey.

\section{REFERENCES}

1. Bharucha AE, Pemberton JH, Locke GR. American gastroenterological association technical review on constipation. Gastroenterology. 2013;144(1):218-38.

2. Papatheodoridis GV, Vlachogiannakos J, Karaitanos I, Karamanolis DG. A Greek survey of community prevalence and characteristics of constipation. European Journal of Gastroenterology \& Hepatology. 2010;22(3):354-60.

3. Schmidt FM, Santos VL. Prevalence of constipation in the general adult population: An integrative review. Journal of Wound Ostomy \& Continence Nursing. 2014;41(1):706; quiz E1-2.

4. Peppas G, Alexiou VG, Mourtzoukou E, Falagas ME. Epidemiology of constipation in Europe and Oceania: A systematic review. BMC Gastroenterology. 2008;8:5.

5. Mulyani NS, Khazanah W, Febrianti S. Asupan serat dan air sebagai faktor risiko konstipasi di kota Banda Aceh. Majalah Kesehatan Masyarakat Aceh (MaKMA). 2019;2(1):75-82.

6. Enck P, Leinert J, Smid M, Kohler T, Schwille-Kiuntke J. Prevalence of constipation in the German population - a representative survey (GECCO). United European Gastroenterology Journal. 2016;4(3):42937.

7. Wald A, Scarpignato C, Kamm MA, Mueller-Lissner S, Helfrich I, Schuijt C, et al. The burden of constipation on quality of life: Results of a multinational survey. Alimentary Pharmacology \& Therapeutics. 2007;26(2):227-36.

8. Belsey J, Greenfield S, Candy D, Geraint M., Systematic review: Impact of constipation on quality of life in adults and children. Alimentary Pharmacology \& Therapeutics. 2010;31(9):938-49. 
9. Chang JY, Locke GR, McNallyMA, Halder SL, Schleck CD, Zinsmeister AR, et al., Impact of functional gastrointestinal disorders on survival in the community. American Journal of Gastroenterology. 2010;105(4):82232.

10. Sommers T, Corban C, Sengupta N, Jones M, Cheng V, BollomA, et al. Emergency department burden of constipation in the United States from 2006 to 2011. American Journal of Gastroenterology. 2015;110(4):5729.

11. Chu H, Zhong L, Li H, Zhang X, Zhang J, Hou $\mathrm{X}$., Epidemiology characteristics of constipation for general population, pediatric population, and elderly population in china. Gastroenterology Research and Practice. 2014;2014:532734.

12. Vazquez Roque M, Bouras EP. Epidemiology and management of chronic constipation in elderly patients. Clinical Interventions in Aging. 2015;10:919-30.

13. WHO. Definition of key terms. 2013; Available from: https://www.who.int/hiv/pub/ guidelines/arv2013/intro/keyterms/en/.

14. Longstreth GF,Thompson WG, Chey WD, Houghton LA, Mearin F, Spiller RC. Functional bowel disorders. Gastroenterology. 2006;130(5):1480-91.

15. Isomura $\mathrm{K}$, Kono $\mathrm{S}$, Moore MA, Toyomura K, Nagano J, Mizoue T, et al. Physical activity and colorectal cancer: The Fukuoka Colorectal Cancer Study. Cancer Science. 2006;97(10):1099-104.

16. Nisa H, Budhathoki S, Morita M, Toyomura K, Nagano J, Ohnaka K, et al. Microsomal epoxide hydrolase polymorphisms, cigarette smoking, and risk of colorectal cancer: The Fukuoka Colorectal Cancer Study. Molecular Carcinogenesis. 2013;52(8):619-26.

17. Andrews CN, Storr M. The pathophysiology of chronic constipation. Canadian Journal of Gastroenterology. 2011;25 Suppl B(Suppl B):16b-21b.

18. Forootan M, Bagheri N, M. Darvishi. Chronic constipation: A review of literature. Medicine (Baltimore). 2018;97(20):e10631.

19. Collete VL, Araujo CL, Madruga SW. Prevalence of intestinal constipation and as- sociated factors: A population-based study in Pelotas, Rio Grande do Sul State, Brazil, 2007. Cadernos de Saude Publica. 2010;26(7):1391-402.

20. Song HJ, Constipation in community-dwelling elders: prevalence and associated factors. Journal of Wound Ostomy \& Continence Nursing. 2012;39(6):640-5.

21. Siproudhis L, Pigot F, Godeberge P, Damon H, Soudan D, Bigard MA. Defecation disorders: A French population survey. Disease of the Colon \& Rectum. 2006;49(2):219-27.

22. Adibi P, Behzad E, Pirzadeh S, Mohseni M.Bowel habit reference values and abnormalities in young Iranian healthy adults. Digestive Disease and Science. 2007;52(8):1810-3.

23. Schmidt FM, Santos VL, Domansky RD, Neves JM. Constipation: Prevalence and associated factors in adults living in Londrina, Southern Brazil. Gastroenterology Nursing. 2016;39(3):204-11.

24. Pena ME, García RJ, Olalla JM, Llanos EV, Miguel AG, Cordero XF Impact of the most frequent chronic health conditions on the quality of life among people aged $>15$ years in Madrid. European Journal of Public Health. 2010;20(1):78-84.

25. Patimah AW, Lee YY, Dariah MY., Frequency patterns of core constipation symptoms among the Asian adults: A systematic review. BMC Gastroenterology. 2017;17(1):115.

26. Bouras EP, Tangalos RG. Chronic constipation in the elderly. Gastroenterology Clinics of North America. 2009;38(3):463-80.

27. Schmidt FM, Santos VL, Domansky RD, Barros E, Bandeira MA, Tenório MA, et al. Prevalence of self-reported constipation in adults from the general population. Revista da Escola de Enfermagem da USP. 2015;49(3):443-52.

28. Lee TH, Choi SC, Park MI, Park KS, Shin JE, Kim SE, et al. Constipation misperception is associated with gender, marital status, treatment utilization and constipation symptoms experienced. Journal of Neurogastroenterology and Motility. 2014;20(3):379-87. 
29. Choung RS, Locke GR, Schleck CD, Zinsmeister AR, Talley NJ. Cumulative incidence of chronic constipation: A population-based study 1988-2003. Alimentary Pharmacology \& Therapeutics. 2007;26(11-12):15218.

30. Mugie SM, Benninga MA, Di Lorenzo C. Epidemiology of constipation in children and adults: A systematic review. Best Practice \& Research Clinical Gastroenterology. 2011;25(1):3-18. 